\title{
STRATEGI PENGEMBANGAN PEMBELAJARAN BERBASIS RISET JURUSAN PENDIDIKAN AGAMA ISLAM
}

\author{
Hariman Surya Siregar \\ harimansuryasiregar@uinsgd.ac.id \\ Jurusan Pendidikan Agama Islam \\ UIN Sunan Gunung Djati Bandung \\ Hamdan Sugilar \\ hamdansugilar@uinsgd.ac.id \\ Prodi Pendidikan Matematika \\ UIN Sunan Gunung Djati Bandung
}

\begin{abstract}
Learning or lecture must be in accordance with the objectives of the lecture expected based on the lecture material indicators. So that the lecture material is supported by data that is valid, up to date and rational research-based lectures are the solution. Thinking activities of students must always be encouraged or given a stimulus so that lecture activities are more meaningful. When the strategy given means that there will be a good response of all student thinking activities must be meaningful in building a frame of mind, for example group discussion activities not only present ideas or ideas but build active communication between students so that a comprehensive understanding of the core themes is born. Research-based learning is based on the results of data studies in the field or literature studies that become research references, and research results should be useful and a valid source for lectures, because research is carried out based on the established university strategic plan. The research-based learning referred to in this study is learning accompanied by research and use the results of research in learning. The results of the study are as follows: $59.46 \%$ of students find it difficult to find
\end{abstract}


research problems so that $89.19 \%$ of students want additional courses on research.

Keywords: research-based learning, Islamic education

\section{A. Pendahuluan}

Pembelajaran merupakan aktivitas fisik dan mental, pada pembelajaran terjadi koneksi antar komponen pembentuk berpikir. Pada pembelajaran diharapkan waktu yang diberikan atau ditempuh memberikan kontribusi positif kepada mahasiswa untuk aktif berpikir dan kritis terhadap kajian materi yang disampaikan oleh dosen. Untuk membangun aktivitas berpikir mahasiswa perlu ada strategi perkuliahan yang mendorong mahasiswa untuk aktif mengkontruksi pikiran yang telah ada dengan stimulus yang diberikan sehingga membentuk pikiran baru yang menjadikan mahasiswa memaknai apa dan mengapa.

Aktivitas berpikir mahasiswa harus senantiasa didorong atau diberikan stimulus agar aktivitas perkuliahan lebih bermakna. Ketika strategi yang diberikan bermakna akan terjadi respon yang baik semua aktivitas berpikir mahasiswa harus bermakna membangun kerangka berpikirnya, misalnya kegiatan diskusi kelompok tidak hanya memaparkan ide atau gagasan tetapi membangun komunikasi aktif antar mahasiswa sehingga lahirnya pemahaman yang komprehensif tentang inti dari tema yang dibahas. Salah satu bagian yang mendorong aktivitas berpikir mahasiswa adalah dengan memberikan materi kuliah berdasarkan fakta, data atau hasil riset sehingga apa yang disampaikan sesuai dengan kondisi yang sebenarnya terjadi. Akhir-akhir ini marak adanya informasi yang keliru tidak berdasarkan fakta dan data atau disebut hoax. Tentu sebagai mahasiswa diharapkan tidak melanjutkan informasi hoax tersebut kepada masyarakat luas, tetapi mahasiswa harus peka dan memberikan penjelasan bahwa informasi itu tidak benar dan menyesatkan sehingga tidak boleh diteruskan. Pembentukan pola berpikir tersebut harus dilatih dan dibiasakan sehingga mahasiswa dapat menggunakan kemampuan berpikir logisnya dengan benar.

Model pembelajaran merupakan salah satu faktor yang mendorong aktivitas berpikir mahasiswa misalnya pembelajaran berbasis riset. Manfaat pembelajaran berbasis riset adalah: Dosen dipaksa untuk belajar hal-hal 
yang terkait dengan artikel yang dipresentasikan; mahasiswa tidak hanya belajar teori. Selain mempelajari teori yang ada pada artikel, mahasiswa tidak hanya belajar tentang ke-ilmuan, tetapi juga belajar tentang penelitian (Mulyaningsih, Indrya, 2016). Visi jurusan Pendidikan Agama Islam Fakultas Tarbiyah dan Keguruan UIN Sunan Gunung Djati adalah menjadi program studi Pendidikan Agama Islam yang unggul, terdepan dan kompetitif dalam bidang PAI di tingkat regional dan nasional tahun 2019 dan salah satu misinya adalah mengembangkan penelitian bidang PAI yang inovatif dan mutakhir sebagai landasan proses pendidikan dan pengabdian kepada masyarakat (KKNI, 2016). Visi dan misi ini akan terwujud apabila civitas akademika bersama-sama satu tujuan untuk mencapainya salah satunya dengan melakukan inovasi dan kreatif dalam pembelajaran, hasil riset dosen atau riset mahasiswa/ skripsi dimanfaatkan atau diterapkan. Model pembelajaran berbasis riset, membutuhkan proses meyakinkan kepada semua dosen bahwa pembelajaran akan lebih berhasil bila menggunakan pembelajaran berbasis riset. Untuk meyakinkan tersebut, maka dibutuhkan informasi-informasi nyata tentang kehandalan model pembelajaran berbasis riset (Masri Kudrat Umar, 2011).

Penelitian tanpa disertai dengan publikasi belum memberikan makna tentang manfaat dan hasil penelitian. Hasil penelitian perlu dipublikasikan atau didesiminasi agar bermanfaat bagi masyarakat (Hamdan Sugilar, 2017). Pembelajaran yang didasari hasil riset memberikan dasar fakta dan data yang real sehingga kajian pembahasan materi lebih komprehensif dan terukur serta up to date. Terdapat beberapa penafsiran tentang pembelajaran berbasis riset, antara lain; (1) pembelajaran menggunakan hasil-hasil riset sebagai bahan material perkuliahan, (2) kegiatan perkuliahan yang dibarengi dengan riset seperti pengumpulan data, pengolahan data, penarikan kesimpulan, dan sebagainya, dan (3) kegiatan perkuliahan yang ditopang oleh sumber belajar yang sangat memadai yaitu penggunaan ICT (Masri Kudrat Umar, 2011). Adapun rumusan masalah: bagaimana model pembelajaran berbasis riset; bagaimana implementasi pembelajaran berbasis riset di prodi pendidikan Agama Islam; dan bagaimana gambaran hasil pembelajaran berbasis riset di prodi pendidikan Agama Islam.

\section{B. Metodologi Penelitian}

Pada penelitian ini mengggunakan dua metode. Metode yang pertama adalah metode design research dengan 3 tahapan, yaitu preliminary 
design, teaching experiment, dan retrospective analysis (Rully Charitas Indra Prahmana, 2016). Penelitian ini mendeskripsikan bagaimana lintasan belajar yang dikembangkan memberikan kontribusi dalam menumbuhkan keterampilan meneliti pada mahasiswa pendidikan Agama Islam, dengan mendeskripsikan kegiatan dosen, mahasiswa, dan melihat hasil akhir pembelajaran, selama kurun waktu mereka menyusun proposal sampai pada bentuk akhir pembuatan jurnal. Metode yang kedua merupakan peneltian riset and development ( $\mathrm{R} \& \mathrm{D})$ Jenis data yang digunakan data kualitatif, karena data yang diperoleh nantinya berupa bukan angka tetapi deskripsi. Subjek penelitian terdiri dari 13 dosen, 37 mahasiswa tingkat akhir yang sedang menyusun skripsi. Teknik Sampling dengan Stratified Sampling.

Adapun subjek dalam penelitian ini adalah Dosen, Mahasiswa semester Genap dan Jurusan Pendidikan Agama Islam. Sumber data berupa: nilai metodologi penelitian, catatan bimbingan skripsi, RPS, SAP atau Silabus Dosen, dan data penelitian dosen.

Uraian kegiatan penelitian terdiri dari: (1) studi pendahuluan SAP dan SilabusMata Kuliah (2) focus group discussion (3) design model dan bahan ajar pembelajaran (4) validasi model dan bahan ajar oleh tim ahli (5) pelaksanaan model pembelajaran berbasis riset (6) wawancara dan penyebaran angket (7) analisis data (6) laporan hasil penelitian. Adapun alur kegiatan penelitian yang akan dilaksanakan disajikan pada bagan sebagai berikut:

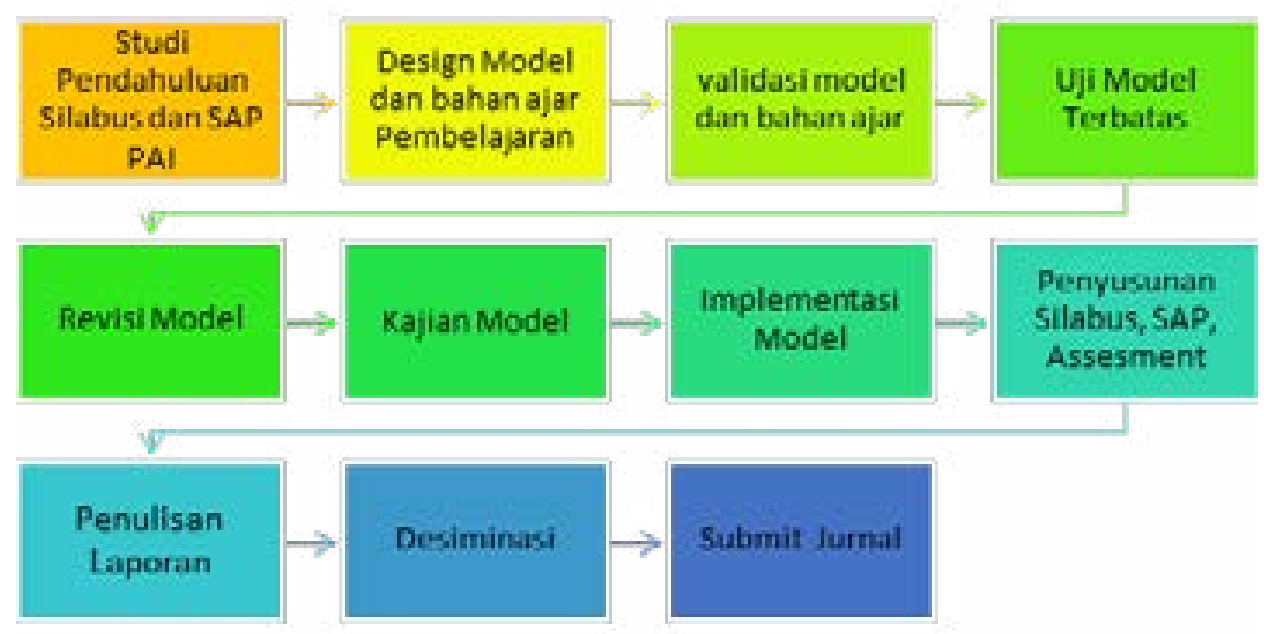




\section{Hasil Penelitian}

1. Visi, Misi dan Tujuan Jurusan Pendidikan Agama Islam

a. Visi Jurusan Pendidikan Agama Islam

Menjadi program studi Pendidikan Agama Islam (PAI) yang unggul, terdepan dan kompetitif dalam bidang PAI di tingkat regional dan nasional tahun 2019.

b. Misi Jurusan Pendidikan Agama Islam

1) Menyiapkan calon pendidik PAI yang berprestasi, kreatif, unggul, profesional, dan berdaya saing;

2) Mengembangkan penelitian bidang PAI yang inovatif dan mutakhir sebagai landasan proses pendidikan dan pengabdian kepada masyarakat;

3) Menyelenggarakan pendidikan dan pengajaran guna menghasilkan lulusan yang menguasai dasar-dasar keahlian dan keterampilan sebagai guru PAI dalam rangka merespon kebutuhan masyarakat.

4) Memberdayakan semua sumber daya yang dimiliki dengan memanfaatkan rekayasa teknologi informasi dan komunikasi (ICT) dalam mengembangkan pembelajaran PAI.

c. Tujuan Jurusan Pendidikan Agama Islam

1) Terciptanya Sarjana Pendidikan Agama Islam yang menguasai dasar-dasar keilmuan, keahlian dan keterampilan sebagai guru Pendidikan Agama Islam.

2) Terciptanya Sarjana Pendidikan Agama Islam yang memiliki kompetensi pedagogik, kepribadian, sosial, profesional, spiritual dan kepemimpinan.

3) Terciptanya Sarjana Pendidikan Agama Islam yang memiliki daya saing secara nasional.

4) Terciptanya Sarjana Pendidikan Agama Islam yang mampu mengembangkan dan menerapkan model-model pembelajaran Pendidikan Agama Islam.

5) Terciptanya Sarjana Pendidikan Agama Islam yang mampu menerapkan ilmu pengetahuan dan keterampilan yang berbasis penelitian. 
6) Terciptanya Sarjana Pendidikan Agama Islam yang berperan aktif dalam mencerdaskan kehidupan bangsa sebagai wujud pengabdian kepada masyarakat, bangsa, dan negara.

2. Profil Lulusan

Pendidik Pendidikan Agama Islam (PAI) pada lembaga sekolah/ madrasah dan luar sekolah yang memiliki kemampuan profesional, berdaya saing serta mampu merespon perkembangan zaman.

3. Capaian Pembelajaran Aspek Pengetahuan

Tujuan perkuliahan harus berdasarkan pada capaian yang ditetapkan pada kurikulum, capaian in menjadi arah dan sasaran yang ingin dicapai oleh jurusan yang implikasinya terhadap kualitas mahasiswa dan lulusan. Capaian pembelajaran pada aspek pengetahuan ini harus ditopang dengan hasil riset-riset yang up to date sehingga kapasitas mahasiswa menjadi lebih baik dan meningkat, melalui penerapan hasil riset dalam perkuliahan diharapkan lebih dinamis dan kaya materi baik hasil riset kuantitatif maupun kualitatif. Adapun capaian pembelajaran pada aspek pengetahuan sebagai berikut:

a. Menguasai konsep PAI berdasarkan Rukun Agama (Islam, Iman, dan Ihsan) yang sesuai dengan Al-Quran dan Al-Hadis.

b. Menguasai konsep dasar kependidikan yang mencakup perkembangan peserta didik, teori- teori belajar, hakikat PAI dan pola pikir ilmiah dalam PAI.

c. Menguasai teori belajar yang berkaitan dengan Al-Quran dan Al-Hadis.

d. Menguasai prinsip-prinsip pengembangan media pembelajaran PAI berbasis ilmu pengetahuan, teknologi yang kontekstual, khususnya TIK (Teknologi Informasi dan Komunikasi), dan lingkungan sekitar berbasis tafsir dan hadits tarbawi tentang etika komunikasi edukatif.

4. Rencana Strategis UIN Sunan Gunung Djati Bandung

Rencana strategis UIN Sunan Gunung Djati Bandung program pengembangan diarahkan menjadi PT yang unggul dan kompetitif berbasis "Wahyu Memandu Ilmu". Kebijakan pengembangan UIN Sunan Gunung Djati berupa upaya penataan dan pengembangan yang akan ditempuh melaui program kebijakan, seperti mendorong dan 
memfasilitasi kreatifitas, dan inovasi dosen untuk menghasilkan karya yang bermanfaat untuk masyarakat, meningkatkan mutu penelitian dosen dan mahasiswa, menghidupkan kembali penerbitan jurnal terakreditasi dan lembaga peneritan, dan mendorong penerbitan jurnaljurnal nasional dan internasional yang terakreditasi (LP2M, 2015). Dari renstra tersebut seluruh civitas akademika senantiasa mampu menjalankan dan melaksanakan strategi penelitian sehingga hasil penelitian dapat bermanfaat dan dirasakan oleh stakeholder dalam hal ini adalah mahasiswa.

Pada periode 2010 sampai tahun 2015 kegiatan penelitian telah menghasilkan 1.784 judul penelitian. Dari tahun 2009 sampai dengan awal tahun 2017, yakni diperolehnya 110 publikasi bereputasi internasional terindeks scopus, dan 133 HKI. Dari data tersebut menempatkan UIN Sunan Gunung Djati Bandung sebagai peringkat II PTKIN publikasi terindeks scopus terbanyak dan peringkat 7 publikasi terindeks scopus perguruan tinggi se- Bandung. Pusat Penelitian dan Penerbitan LP2M UIN Sunan Gunung Djati Bandung mempunyai peran yang sangat strategis sebagai leading sector dalam pelaksanaan kegiatan penelitan. LP2M sendiri mempunyai tugas melaksanakan, mengoordinasikan, memantau dan menilai kegiatan penelitian dan pengabdian kepada masyarakat berdasarkan kebijakan Rektor (Rencana Induk Penelitian UIN Sunan Gunung Djati, 2015). Geliat penelitian dan publikasi yang potensial membentuk kultur akademik yang kondusif bagi pengembangan penelitian dan publikasi yang harus berimplikasi pada peningkatan kualitas pembelajaran melalui pembelajaran berbasis riset (Darmalaksana, 2017). Penelitian dan publikasi telah menjadi kebutuhan mendasar sivitas akademik UIN Bandung yang harus dibarengi dengan pemanfaatan publikasi untuk peningkatan kualitas pembelajaran atau perkuliahan.

\section{Pembelajaran Berbasis Riset}

Pembelajaran berbasis riset didasari filosofi konstruktivisme yang mencakup 4 (empat) aspek yaitu: pembelajaran yang membangun pemahaman mahasiswa, pembelajaran dengan mengembangkan prior knowledge, pembelajaran yang merupakan proses interaksi sosial dan pembelajaran bermakna yang dicapai melalui pengalaman nyata. (Diah Tri Widayati, 2010). Esensi dari teori konstruktivisme adalah ide bahwa 
siswa harus menemukan dan mentransformasikan suatu informasi kompleks ke situasi lain, dan apabila dikehendaki informasi itu menjadi milik mereka sendiri (Sagala, 2010). Beberapa strategi dalam memadukan pembelajaran dan riset yang secara empirik dikembangkan di Griffith University

1. Memperkaya bahan ajar dengan hasil penelitian dosen . Pada proses pembelajaran ini hasil penelitian dosen digunakan untuk memperkaya bahan ajar.

2. Menggunakan temuan-temuan penelitian mutakhir dan melacak sejarah ditemukannya perkembangan mutakhir tersebut. Pada proses pembelajaran ini, temuan-temuan penelitian mutakhir yang diperoleh dari pustaka didiskusikan untuk mendukung materi pokok bahasan yang sesuai

3. Memperkaya kegiatan pembelajaran dengan isu-isu penelitian kontemporer Pada proses pembelajaran ini dapat dimulai dengan meminta peserta didik menyampaikan isu-isu penelitian yang ada pada saat ini, yang sesuai dengan pokok bahasan

4. Mengajarkan materi metodologi penelitian di dalam proses pembelajaran

5. Memperkaya proses pembelajaran dengan kegiatan penelitian dalam skala kecil

6. Pada proses pembelajaran ini, kelompok peserta didik diberi tugas melakukan penelitian bersama. Dengan demikian peserta didik dapat meningkatkan ketrampilan dan pengetahuan dari kegiatan tersebut

7. Memperkaya proses pembelajaran dengan melibatkan peserta didik dalam kegiatan penelitian institusi

8. Memperkaya proses pembelajaran dengan mendorong peserta didik agar merasa menjadi bagian dari budaya penelitian di fakultas/ jurusan

9. Memperkaya proses pembelajaran dengan nilai-nilai yang harus dimiliki oleh peneliti 
Nilai-nilai yang harus dimiliki oleh peneliti seharusnya perlu dipahami oleh peserta didik. Nilai-nilai tersebut antara lain: objektivitas, penghargaan akan temuan penelitian, respek pada pandangan lain, toleransi terhadap ketidakpastian, dan kemampuan analisis (Diah Tri Widayati, 2010).Prinsip Strategi Penelitian Pembelajaran dan Pengajaran berbasis penelitian yang dikemukakan oleh Pusat Pengantar Keunggulan Eberly, Universitas Carnegie Mellon sebagai berikut:

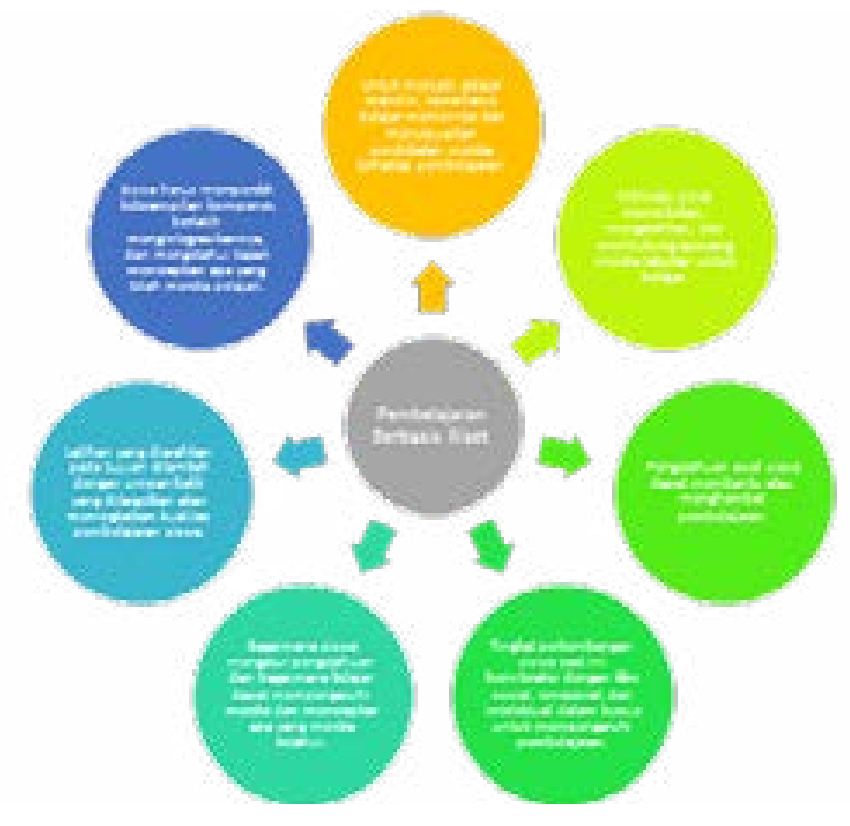

Bagan 1. Prinsip Strategi Pembelajaran dan Pengajaran berbasis penelitian (Carnegie, 2017)

1. Pengetahuan awal siswa dapat membantu atau menghambat pembelajaran.

Seiring siswa membawa pengetahuan ini ke dalam kelas kita, hal itu mempengaruhi bagaimana mereka memfilter dan menafsirkan apa yang mereka pelajari. Jika pengetahuan awal siswa kuat dan akurat dan diaktifkan pada waktu yang tepat, maka pengetahuan dasar yang kuat untuk membangun pengetahuan baru. Namun, bila pengetahuan itu inert, tidak mencukupi untuk tugas tersebut, diaktifkan secara tidak tepat, atau tidak akurat, hal itu dapat mengganggu atau menghambat pembelajaran baru. Untuk menerapkan prinsip ini, perhatikan teknik pengajaran berikut ini:Berikan penilaian diagnostik atau mintalah siswa menilai pengetahuan sebelumnya (lihat "Teknik Penilaian Kelas 
Terpilih (CATs) untuk Mendapatkan Masukan tentang Pembelajaran Siswa,").Gunakan brainstorming untuk mengungkapkan pengetahuan sebelumnya. Identifikasi konvensi khusus disiplin secara eksplisit.

2. Motivasi siswa menentukan, mengarahkan, dan mendukung apa yang mereka lakukan untuk belajar.

Ketika siswa masuk perguruan tinggi dan mendapatkan otonomi yang lebih besar mengenai apa, kapan, dan bagaimana mereka belajar dan belajar, motivasi memainkan peran penting dalam membimbing arah, intensitas, ketekunan, dan kualitas perilaku belajar di mana mereka terlibat. Ketika siswa menemukan nilai positif dalam tujuan atau aktivitas belajar, berharap berhasil mencapai hasil belajar yang diinginkan, dan merasakan dukungan dari lingkungan mereka, mereka cenderung sangat termotivasi untuk belajar. Untuk menerapkan prinsip ini, perhatikan teknik pengajaran berikut ini:

\section{Bagaimana siswa mengatur pengetahuan pengaruhnya}

Siswa secara alami membuat hubungan antara bagian pengetahuan. Ketika koneksi tersebut membentuk struktur pengetahuan yang disusun secara akurat dan bermakna, siswa lebih mampu untuk mengambil dan menerapkan pengetahuan mereka secara efektif dan efisien. Sebaliknya, ketika pengetahuan terhubung secara tidak akurat atau acak, siswa dapat gagal untuk mengambil atau menerapkannya dengan tepat. Untuk menerapkan prinsip ini, perhatikan teknik pengajaran berikut ini:

\section{Mengembangkan Penguasaan, Pengetahuan dan Keterampilan}

Siswa harus mengembangkan bukan hanya keterampilan komponen (yaitu keterampilan dasar) dan pengetahuan yang diperlukan untuk melakukan tugas yang kompleks, siswa juga harus berlatih menggabungkan dan mengintegrasikannya untuk mengembangkan kefasihan dan keotentikan yang lebih baik. Akhirnya, siswa harus belajar kapan dan bagaimana menerapkan keterampilan dan pengetahuan yang mereka pelajari. Sebagai instruktur, penting bagi kita untuk mengembangkan kesadaran sadar akan unsur penguasaan ini sehingga bisa membantu siswa kita belajar lebih efektif. Untuk menerapkan prinsip ini, perhatikan teknik pengajaran berikut ini:Berikan praktek keterampilan lemah atau hilang yang terisolasi.Beri kesempatan 
kepada siswa untuk mempraktikkan keterampilan termasuk taruhan rendah, tugas yang tidak diolah (lihat "Teknik Penilaian Kelas Terpilih (CATs) untuk Mendapatkan Masukan tentang Pembelajaran Siswa,"). Berikan kesempatan kepada siswa untuk menerapkan keterampilan atau pengetahuan dalam konteks yang beragam. Tentukan keterampilan atau pengetahuan dan mintalah siswa untuk Mengidentifikasi konteks di mana mereka mendaftar.

\section{Latihan yang diarahkan dan Umpan Balik}

Pembelajaran dan kinerja paling baik dipupuk ketika siswa terlibat dalam praktik yang berfokus pada sasaran atau kriteria tertentu, menargetkan tingkat tantangan yang sesuai, dan memiliki jumlah dan frekuensi yang cukup untuk memenuhi kriteria kinerja. Praktik harus digabungkan dengan umpan balik yang secara eksplisit mengkomunikasikan beberapa aspek kinerja siswa dibandingkan dengan kriteria target tertentu, memberikan informasi untuk membantu kemajuan siswa dalam memenuhi kriteria tersebut, dan diberikan pada waktu dan frekuensi yang memungkinkannya bermanfaat. . Untuk menerapkan prinsip ini, perhatikan teknik pengajaran berikut ini:

\section{Tingkat perkembangan}

Siswa tidak hanya intelektual tapi juga makhluk sosial dan emosional, dan mereka masih mengembangkan berbagai keterampilan intelektual, sosial, dan emosional. Meskipun kita tidak dapat mengendalikan proses perkembangan, kita dapat membentuk iklim kelas dengan cara yang sesuai dengan perkembangan. Sebenarnya, banyak penelitian telah menunjukkan bahwa iklim yang kita ciptakan memiliki implikasi bagi siswa kita. Iklim negatif dapat menghambat pembelajaran dan kinerja, namun iklim positif dapat memberi energi pada pembelajaran siswa. Untuk menerapkan prinsip ini, perhatikan teknik pengajaran berikut ini:

7. Monitor dan Penyesuaian Pendekatan Siswa terhadap Pembelajaran.

Peserta didik dapat terlibat dalam berbagai proses metakognitif untuk memantau dan mengendalikan pembelajaran mereka - menilai tugas yang sedang dihadapi, mengevaluasi kekuatan dan kelemahan mereka sendiri, merencanakan pendekatan mereka, menerapkan dan memantau berbagai strategi, dan merenungkan sejauh 
mana pendekatan mereka saat ini adalah kerja. Sayangnya, siswa cenderung tidak terlibat dalam proses ini secara alami. Ketika siswa mengembangkan keterampilan untuk melibatkan proses ini, mereka mendapatkan kebiasaan intelektual yang tidak hanya memperbaiki kinerja mereka, tetapi juga efektivitasnya sebagai peserta didik. Untuk menerapkan prinsip ini, perhatikan teknik pengajaran berikut ini: Periksa pemahaman siswa tentang tugas tersebut. Mintalah siswa melakukan penilaian diri secara terpuji Mengharuskan siswa untuk merenungkan dan memberi keterangan tentang pekerjaan mereka sendiri. Meminta siswa untuk menganalisis keefektifan kemampuan belajar mereka.

Tabel 1. Angket Kemampuan Mahasiswa dalam Menyusun Rencana Penelitian

\begin{tabular}{|l|l|l|l|}
\hline No & Pernyataan & Ya (\%) & $\begin{array}{c}\text { Tidak } \\
(\%)\end{array}$ \\
\hline $\begin{array}{l}\text { Saya merasa kesulitan dalam mencari masalah } \\
\text { penelitian }\end{array}$ & 59.46 & 40.54 \\
\hline $\begin{array}{l}\text { Menurut saya materi kuliah tentang penelitian } \\
\text { perlu ditambah }\end{array}$ & 89.19 & 10.81 \\
\hline $\begin{array}{l}\text { Saya mengalami kesulitan dalam menyusun pro- } \\
\text { posal penelitian }\end{array}$ & 32.43 & 67.57 \\
\hline $\begin{array}{l}\text { Saya merasa kesulitan dalam mencari referensi } \\
\text { penelitian berupa Jurnal }\end{array}$ & 62.16 & 37.84 \\
\hline $\begin{array}{l}\text { Saya merasa kebingungan dalam membuat ru- } \\
\text { musan masalah }\end{array}$ & 68.92 & 31.08 \\
\hline $\begin{array}{l}\text { Pedoman skripsi yang ada sangat membantu saya } \\
\text { dalam membuat skripsi }\end{array}$ & 89.19 & 10.81 \\
\hline
\end{tabular}

Tabel tersebut yang diberikan kepada mahasiswa tingkat akhir yang sedang menyusun skripsi 59,46 \% mahasiswa kesulitan mencari masalah penelitian, umumnya mahasiswa hanya memodifikasi judul penelitian yang ada tanpa adanya observasi atau kajian terhadap masalah yang harus diselesaikan tampak pada latar belakang masalah yang tingkat kontibusi terhadap ilmu atau masyarakat masih rendah. Karena kesulitan dalam menentukan masalah penelitian atau tentang metodologi penelitian 89,19\% mahasiswa menginginkan adanya 
tambahan mata kuliah tentang penelitian. Sehingga $62,16 \%$ mahasiswa merasa kesulitan dalam mencari referensi penelitian berupa jurnal hal ini perlu mendapatkan arahan tentang bagaimana cara mengakses jurnal dan cara mengkaji jurnal pada bagian mana kita dapat menggunakan jurnal sebagai referensi penelitian. 68, $92 \%$ merasa kebingungan membuat rumusan masalah, hasil wawancara dengan mahasiswa yang sedang menyusun skripsi menyatakan bahwa rumusan masalah yang dibuat hasil melihat dari rumusan masalah penelitian orang lain tanpa adanya kesesuaian dengan penelitian yang dilakukan. Penelitian yang akan dilaksanakan harus berdasarkan kajian penelitian sebelumnya agar penelitian yang dilakukan lebih sinergis dan berdaya manfaat. State of the art penelitian mendorong agar posisi penelitian yang dilakukan memiliki kebaruan.

Tabel 2. Angket Kemampuan Mahasiswa dalam Melaksanakan Penelitian

\begin{tabular}{|l|l|l|l|}
\hline No & Pernyataan & Ya (\%) & $\begin{array}{c}\text { T i d a k } \\
(\%)\end{array}$ \\
\hline $\begin{array}{c}\text { Saya mampu melakukan observasi untuk men- } \\
\text { cari informasi dan metodologi yang dibu- } \\
\text { tuhkan }\end{array}$ & 83.78 & 16.22 \\
\hline Saya mampu membuat design penelitian & 64.86 & 35.14 \\
\hline $\begin{array}{l}\text { Saya mampu memilah dan mendeskripsikan } \\
\text { data penelitian yang telah dikumpulkan }\end{array}$ & 81.08 & 18.92 \\
\hline $\begin{array}{c}\text { Saya mampu menganalisis data penelitian un- } \\
\text { tuk menjawab rumusan masalah. }\end{array}$ & $\begin{array}{l}\text { Saya mampu membuat referensi manager den- } \\
\text { gan baik }\end{array}$ & 27.30 & 2.70 \\
\hline & $\begin{array}{c}\text { Saya merasa terbebani dalam membuat skripsi } \\
\text { Menurut saya lebih baik kuliah daripada mem- } \\
\text { buat skripsi }\end{array}$ & 8.11 & 96.76 \\
\hline $\begin{array}{c}\text { Pedoman skripsi yang ada sangat membantu } \\
\text { saya dalam membuat skripsi }\end{array}$ & 85.95 & 54.05 \\
\hline
\end{tabular}

$83,78 \%$ mahasiswa mampu melakukan observasi untuk mencari informasi dan metodologi yang dibutuhkan, berarti mahasiswa telah memahami tentang langkah dan metode penelitian yang akan dilakukan 
yang implikasinya $64,86 \%$ mahasiswa mampu membuat design penelitian. Lebih dari $50 \%$ mahasiswa mampu membuat design, menganalisis data hasil penelitian. Namun 45,95 \% mahasiswa menyatakan bahwa lebih baik kuliah daripada menyusun skripsi hal ini perlu mendapatkan perhatian agar mahasiswa terbiasa dengan melakukan riset. Dengan adanya pedoman skripsi mahasiswa merasa terbantu dalam membuat skripsi.

Tabel 3. Angket Pemanfaatan Penelitian Sebagai Referensi Perkuliahan

\begin{tabular}{|l|l|l|l|}
\hline No & Pernyataan & Ya & Tidak \\
\hline & $\begin{array}{l}\text { Referensi yang digunakan pada kuliah salah satun- } \\
\text { ya berupa jurnal }\end{array}$ & 84.62 & 15.38 \\
\hline $\begin{array}{l}\text { Referensi yang digunakan dalam membuat SAP, } \\
\text { Silabus atau RPS }>3 \text { jurnal }\end{array}$ & 38.46 & 61.54 \\
\hline $\begin{array}{l}\text { Saya merasa kesulitan dalam menemukan jurnal } \\
\text { yang relevan dengan mata kuliah yang diampu }\end{array}$ & 30.77 & 69.23 \\
\hline $\begin{array}{l}\text { Jumlah hasil riset saya pada 3 tahun terakhir >3 } \\
\text { judul riset }\end{array}$ & 53.85 & 46.15 \\
\hline $\begin{array}{l}\text { Riset yang saya lakukan berkaitan dengan mata } \\
\text { kuliah yang diampu }\end{array}$ & 61.54 & 38.46 \\
\hline $\begin{array}{l}\text { Saya sering mengakses jurnal hasil penelitian } \\
\text { Saya memiliki artikel jurnal hasil penelitian > 3 } \\
\text { artikel }\end{array}$ & 69.23 & 30.77 & 69.23 \\
\hline $\begin{array}{l}\text { Materi kuliah yang disampaikan kepada maha- } \\
\text { siswa berdasarkan hasil-hasil riset }\end{array}$ & 53.85 & 46.15 \\
\hline
\end{tabular}

$84,62 \%$ menyatakan bahwa dosen menggunakan referensi jurnal sebagai materi kuliaj namun hanya 38,46\% dosen menggunkana dalam membuat SAP, silabus atau RPS lebih dari 3 jurnal ini berarti hasil riset yang telah terpublikasi pada jurnal belum sepenuhnya digunakan sebagai bahan referensi kuliah yang disampaikan kepada mahasiswa 61,54\% dosen menggunakan referens jurnal kurang dari 3 jurnal jadi masih sedikit sumber materi kuliah dari jurnal-jurnal. Ada beberapa faktor dosen kurang memanfaatkan jurnal sebagai referensi perkuliahan salah satunya 69,23\% dosen merasa kesulitan dalam menemukan jurnal yang relevan dengan mata kuliah yang diampu. Faktor lainnya karena minnimnya dosen melakukan 
riset ini dapat dilihat dari jumlah hasil riset dosen pada 3 tahun terakhir lebih dari 3 judul riset hanya 53,85\% sehingga setengahnya dosen aktif melakukan riset atau penelitian

\section{Kesimpulan dan Saran}

Pembelajaran bebasis riset merupakan pembelajaran yang didalamnya terdiri dari riset atau pembelajaran yang referensinya berdasarkan hasil riset. Nilai-nilai riset, hasil-hasil riset dan cara-cara riset yang dilakukan oleh civitas akademik dapat dimanfaatkan menjadi materibelajar dan cara-belajar. Hasil penelitian menunjukkan hasil riset belum sepenuhnya dimanfaatkan dalam pembelajaran atau perkuliahan hal ini dapat dilihat dari referensi SAP yang dibuat dosen dan referensi atau daftar pustaka pada skripsi yang dibuat.

\section{REFERENSI}

Ahmad Tafsir, Asep Nursobah. 2009. Filsapat Dan Metode Berfikir. Jakarta: Dijen Pendidikan Islam Departemen Agama.

Carnegie Mellon University. 2017. Research-based Principles of Learning \& Teaching Strategies. Eberly Center for Teaching Excellence, [Online] Available at: http:// http://www.crlt.umich.edu/gsis/p4_7. [Accessed 17 December 2017].

Darmalaksana, W., 2017. ANALISIS KULTUR PENELITIAN DAN PUBLIKASI UIN SUNAN GUNUNG DJATI BANDUNG. [Online] Available at: http://digilib.uinsgd.ac.id/4961/_Accessed 17 December 2017].

Diah Tri Widayati, d., 2010. Pedoman Umum Pembelajaran Berbasis Riset. Yogyakarta: UGM.

Hamdan Sugilar, T. P. W. D., 2017. Strategi Perguruan Tinggi dalam Akselerasi Hasil Penelitian. Bandung, ICSE UPI.

KKNI, T. P., 2016. Kurikulum Jurusan PAI Mengacu kepada KKNI dan $S N P T$. Bandung, Jurusan PAI FTK UIN SGD Bandung. 
LP2M, P. P. dan P. (2015a) Profil Pusat Penelitian dan Penerbitan.Bandung: Puslitpen UIN Sunan Gunung Djati

LP2M, P. P. dan P. (2015a) Profil Pusat Penelitian dan Penerbitan. Bandung: Puslitpen UIN Sunan Gunung Djati

LP2M, P. P. dan P. (2015b) Standar Operasional Prosedur. Bandung: Puslitpen UIN Sunan Gunung Djati

LP2M, P. P. dan P. (2017) Panduan Pelaksanaan Penelitian dan Publikasi 2017. Bandung: Puslitpen UIN Sunan Gunung Djati

Masri Kudrat Umar, S. M. d., 2011. Pengembangan Pembelajaran Berbasis Riset di Program Studi PendidikanFisika FMIPA Universitas Negeri Gorontalo, Gorontalo: Universitas Negeri Gorontalo.

Mulyaningsih, Indrya, 2016. Pembelajaran Berbasis Riset Pada Mata Kuliah 'Teori Belajar Bahasa'. Sukoharjo, Universitas Veteran Bantara Sukoharjo.

Rencana Induk Penelitian UIN Sunan Gunung Djati (2015). Bandung: LP2M UIN Sunan Gunung Djati

Sagala, S., 2010. Konsep dan Makna Pembelajaran. Bandung: Alfabeta. 